\title{
TP53BP1 Gene
}

National Cancer Institute

\section{Source}

National Cancer Institute. TP53BP1 Gene. NCI Thesaurus. Code C88925.

This gene may play a role in the modulation of the response to DNA damage. 